\title{
REASONS FOR DIFFERENCE BETWEEN REAL AND \\ PROJECTED OPERATING SUPPLIES FOR SUPPORTING DURING CONSTRUCTION OF RAMPS
}

\section{UPOREĐENJE POTROŠENENIH I PROJEKTOVANIH KOLIČINA PODGRADNIH MATERIJALA TOKOM IZRADE OTKOPNE RAMPE}

\author{
Doneva Nikolinka ${ }^{1}$, Despodov Zoran ${ }^{1}$, Mirakovski Dejan ${ }^{1}$, \\ Hadži-Nikolova Marija ${ }^{1}$, Mijalkovski Stojanče ${ }^{1}$
}

Received: April 24, 2016

Accepted: May 15, 2016

\begin{abstract}
Exactly established longitudinal profile, as well as physical mechanical properties of all lithological units along the route of a mining facility are very important for the design of an underground mining facilities. This paper presents the construction of ramp in an underground mine in Macedonia, where real and projected supporting operating supplies are compared.
\end{abstract}

Key words: engineering - mining profile, costs, ramps

\begin{abstract}
Apstrakt: Od presudne važnosti kod projektovanja podzemnih prostorija je tačno utvrđen profil kroz osu buduće trase, kao i fizičko-mehaničke osobine svih litoloških jedinica po trasi prostorije. Problemi koji se mogu javiti, zbog loše sprovedenih ispitivanja terena, tokom realizacije same izrade su višestruki. U ovom radu prikazana je izrada otkopne rampe $u$ podzemnom rudniku $u$ Makedoniji. Pri tome upoređene su realno utrošene i projektovanekoličine podgradnih materijala.
\end{abstract}

Ključne reči: inženjerstvo - rudarski profili, troškovi, otkopne rampe

\section{INTRODUCTION}

The rock material is composed of rocks with different age, origin and mineral composition, which are exposed to various influences that caused very different characteristics at the same rock material, but that means a variety of mining-geological conditions. For these reasons, it can not be accepted that along the route on underground mining facility the rock material will be homogenous and unique in terms of its composition, behavior and properties, but very different and heterogeneous. Therefore, it is necessary for a detailed engineering and geological surveys to be performed along the route on underground mining facility. Based on the results, zones

${ }^{1}$ Faculty of Natural and Technical Sciences, University "Goce Delčev" - Štip, Goce Delčev 89, 2000 Štip, Macedonia, e-mails: nikolinka.doneva@ugd.edu.mk; zoran.despodov@ugd.edu.mk;

dejan.mirakovski@ugd.edu.mk; marija.hadzi-nikolova@ugd.edu.mk; stojance.mijalkovski@ugd.edu.mk 
will be established for which approximately same engineering and geological conditions can be assumed (Brady and Brown, 2004).

Regardless of their function, underground mining facilities present linear structures, so engineering - geological profiles serve as basis for their design and construction. Engineering - geological profiles present a longitudinal section through the rock material in direction of the underground mining facility and they are performed based on the data obtained from the surveys. These profiles show: lithological composition, construction, cracks, decay volume and other properties of rock material along the facility alignment.

Engineering-geological profiles present a base for further research and construction of engineering - mining profiles. For this purpose, detailed mining surveys of narrow zones around the mining facility are performed. That is the way to establish and explain the rock material behavior before, during and after the construction of an underground facility. To determine the rock material behavior it is necessary for the following things to be determined: structural, physical, mechanical, technological, hydrological and stress-deformation conditions in rock mass around the underground mining facility. Engineering - mining profiles usually are performed as longitudinal as well as cross-section profiles along the mining facility alignment (Jovanović, 1994).

\section{SUBLEVEL STOPPING METHOD}

Sublevel stopping methods are applied for excavation of stratified deposits with small, medium or large thickness. In case of small thickness it is best for the orebody thickness to be equal with the height of slope (up to $2.5 \mathrm{~m}$ ) and if the thickness is greater, then the excavation is performed in several sublevels. At this excavation method, the physical-mechanical characteristics of overburden are most important because of the stope security. After completing the excavation, the overbuden should be caved into small pieces and to be done immediately after removing support. The caving of the overburden brings the release of the generated stress in rock material and unloading of support (Torbica \& Petrović, 1997).

\subsection{Preparation works}

Preparation works for excavation of blocks include construction of more mining preparation facilities as follows:

- $\quad$ Ramp (R);

- $\quad$ Ringodrilling drift (RD);

- $\quad$ Sublevel drift (SD);

- $\quad$ Ore pass and waste pass (OP and WP);

- Ventilation raise (VR);

- $\quad$ Cut raise (CR).

Ramps present slightly inclined mining facilities, intended about:

- Conection of individual excavated levels (sublevels) with opening facilities;

- $\quad$ Ore and waste-rock transportation from slope to the ore pass;

- $\quad$ Transport of employees to workplace; 
- $\quad$ Ventilation of stope - workplaces;

- $\quad$ Stope servicing with necessary raw materials and energy.

Ramps are constructed in footwall at distance of minimum 15 to 20 meters of ore body. The direction of ramps development is usually from the top to down, and they should be constructed to capital drift in footwall in order to connect with lower horizon. The length of individual ramps is approximately equal and it is determined by the height between horizons or angle of ore dip, number of excavated levels-sublevels, slope and curves radius. Commonly, ramps are constructed in spiral form and consist of segments including: inclined, horizontal and curves. Slope of ramps amounts $10 \%$ to $15 \%$ (10\% in curves, while $15 \%$ on rest route).

The ramp function is to overcome the difference of height between two excavated levels; the number of excavated levels determines the number of ramps, while the height of excavated levels and slopes of ramps determine their length.

\section{PROJECTED AND REAL OPERATING SUPPLIES FOR SUPPORTING DURING CONSTRUCTION OF RAMPS}

\subsection{Design backgrounds}

Data analysis about projected and real operating supplies for supporting during construction of ramps was performed for the purpose of this paper. Consumption of supporting material about the object's length of $20 \mathrm{~m}$ was analyzed.

The shape of the ramp cross section is horse - shoe shaped, while the dimensions of the cross section are: width $\mathrm{B}=3.5 \mathrm{~m}$, height $\mathrm{H}=3.75 \mathrm{~m}$ and height of wall by $\mathrm{h}=2.0 \mathrm{~m}$. Cross section area is: $\mathrm{S}=11.8 \mathrm{~m}^{2}$.

Ramp is constructed in footwall of ore body that consists of gneiss with different structural characteristics. Physical - mechanical characteristics of rock material are given as a design background (Table 1), obtained in laboratory.

Table 1 - Physical-mechanical characteristics of rock material

\begin{tabular}{|c|c|c|c|c|c|c|c|}
\hline $\begin{array}{c}\text { Rock } \\
\text { type }\end{array}$ & $\begin{array}{c}\gamma \\
{\left[\mathbf{t} / \mathbf{m}^{\mathbf{3}}\right]}\end{array}$ & $\begin{array}{c}\boldsymbol{\sigma}_{\mathbf{c}} \\
{[\mathbf{M P a}]}\end{array}$ & $\begin{array}{c}\sigma_{\mathbf{t}} \\
{[\mathbf{M P a}]}\end{array}$ & $\begin{array}{c}\mathbf{C} \\
{[\mathbf{M P a}]}\end{array}$ & $\begin{array}{c}\boldsymbol{\varphi} \\
{\left[{ }^{\circ}\right]}\end{array}$ & $\boldsymbol{v}$ & $\begin{array}{c}\mathbf{E x 1 0} \\
{[\mathbf{M P a}]}\end{array}$ \\
\hline \hline Gneiss & $2.7-2.8$ & $65-93$ & $12-17$ & $10-31$ & $34-41$ & $0.16-0.18$ & $39-45$ \\
\hline
\end{tabular}

Route of ramp (ie analyzed $20 \mathrm{~m}$ ) will pass through class II $(10 \mathrm{~m})$ and class III $(10 \mathrm{~m})$ of rock material. Route of ramp with its geometric elements in plan is shown on Figure 1. 


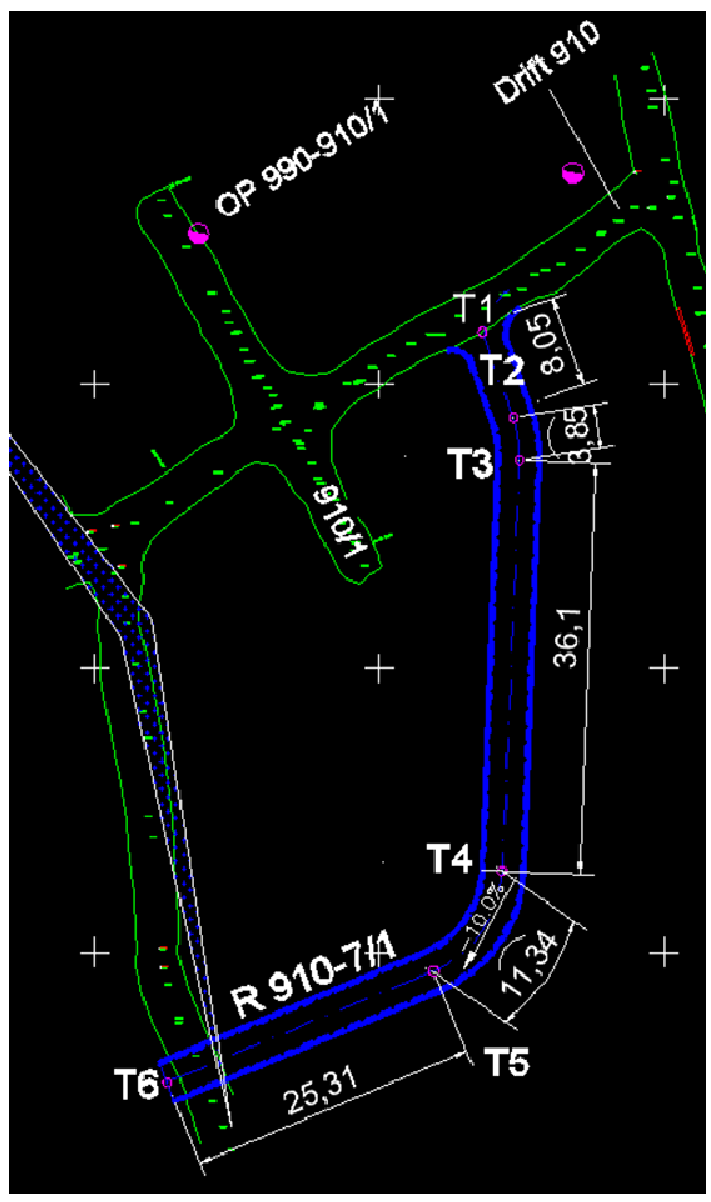

Figure 1 - Review of ramp's route

Table 2 - Geometric elements of ramp

\begin{tabular}{|c|c|c|c|c|}
\hline Position & $\begin{array}{c}\text { Length } \\
{[\mathbf{m}]}\end{array}$ & $\begin{array}{c}\text { Slope } \\
{[\mathbf{\%}]}\end{array}$ & $\begin{array}{c}\text { Elevation } \\
{[\mathbf{m}]}\end{array}$ & $\begin{array}{c}\text { Height } \\
{[\mathbf{m}]}\end{array}$ \\
\hline \hline $1-2$ & 8.05 & 4 & 910.30 & 0.32 \\
\hline $2-3$ & 3.85 & 9 & 909.98 & 0.35 \\
\hline $3-4$ & 36.00 & 15 & 909.63 & 5.40 \\
\hline $4-5$ & 11.34 & 10 & 904.23 & 1.13 \\
\hline $5-6$ & 25.31 & 0 & 903.10 & 0.00 \\
\hline$\Sigma$ & 84.55 & & & 7.20 \\
\hline
\end{tabular}

\subsection{Elastic support}

It was decided that during design that the elastic support is most appropriate. This type of support belongs in combined supports. In practice it exists in various combinations of shotcrete with other types of supporting material: 


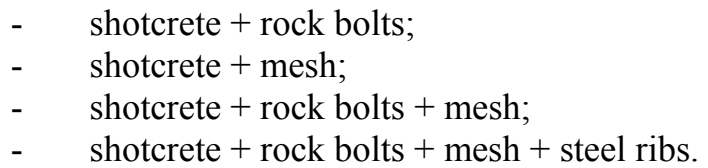

New Austrian method in terms of supporting materials is actually elastic support.

The New Austrian Tunneling Method (NATM) grew out of experience with the old methods. In his book "Gebirgsdruck und Tunnelbau" 1944, Prof. L.v. Rabcewicz published a systematization of rock pressure phenomena and their interpretation. In his Patent of 1948, the basic principles of the concept were formulated. The essence was as follows:

With a flexible primary support a new equilibrium shall be reached. This shall be controlled by in-situ deformation measurements. After this new equilibrium is reached, an inner arch shall be built. In specific cases the inner arch can be omitted.

Application of this method enables the improvement of: support means and auxiliary measures, instrumentation and interpretations techniques. Besides in tunnel construction, further application of NATM is expanded also in mining during construction of horizontal mining facilities. NATM is universal method, especially suitable for irregular shapes. Therefore it can be applied to other types of underground facilities with differently shaped cross-section and diameter.

The essence of this supporting method of underground mining facilities and tunnels is that the part of the rocks around the facility profile themselves will be part of this support structure. Elastic construction of this supporting system easily accepts deformations occurring in redistribution of stresses in masses around the profile until finally the balance is reached. Shotcrete compared to monolithic concrete has 2 to 2.5 times better ability to bind with rock mass. Shotcrete is implanted under pressure which enables its penetration into cracks and thus better stabilization of rock mass.

Immediately after facility excavation, next to the face, the first shotcrete layer is applied on contour with thickness of $3 \mathrm{~cm}$ to $7 \mathrm{~cm}$. This layer acts as a temporary support and besides the protection role it acts as an injection means, because along the cracks and micro-cracks, to a certain depth, shotcrete penetrates into the rock mass and thus connects blocks separated by cracking on surface, prevents their movement and increases the stability of exposed rock. When deformation of underground facility contour is finished, the mesh and rock bolts are set (if necessary steel ribs are also set). Mesh is well placed if it follows the contour of an excavated profile. After this, second - carrier layer is applied (with designed thickness), in order covering all cracks that occurred after the placement of the first layer, and to give the final shape for support.

Functionally elastic support can be divided into two arches (Figure 2):

- Outer arch, made of shotcrete and mesh, which carries stabilization of contour profile - plastic zone;

- Inner arch of surround rocks, connected by rock bolts with unchanged mass etc. natural arch, which compose carrier zone - elastic zone (Донева, 2011). 


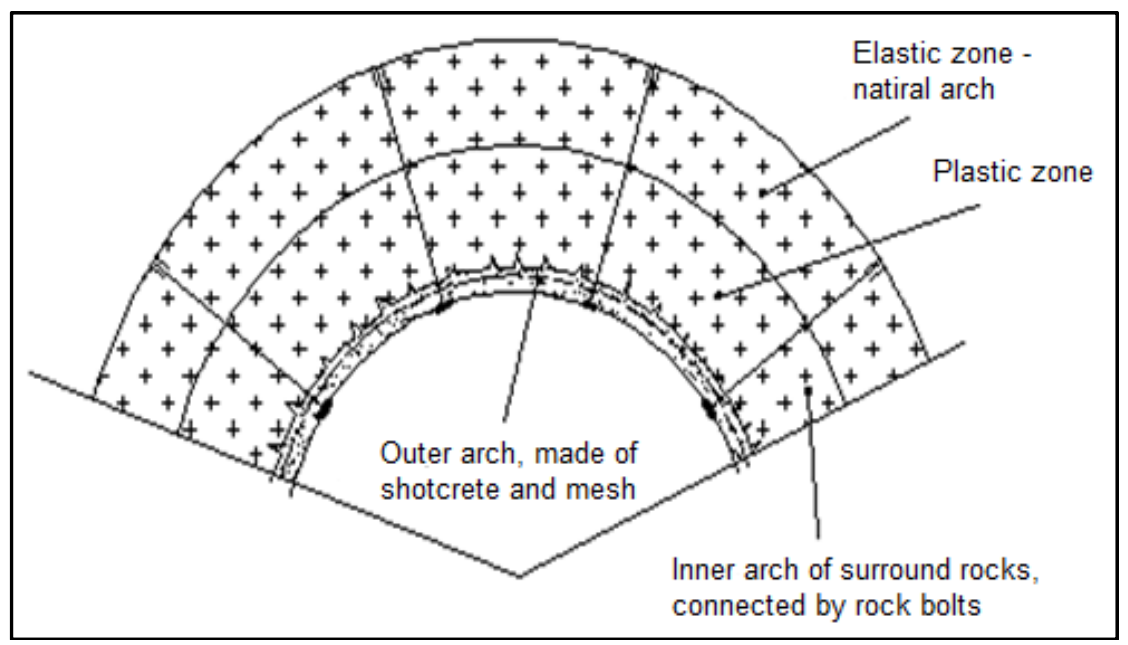

Figure 2 - Zones of elastic support

\subsection{Comparison of projected and real operating supplies for supporting}

In present case, because of relatively compact rock material, it was decided for the following materials to be icluded in supporting construction: shotcrete, steel mesh and rock bolts. According to the project, for the analyzed $20 \mathrm{~m}$, the following materials were predicted for consumption:

$\begin{array}{lll}\text { - } & \text { Cement } & 5970 \mathrm{~kg} \\ \text { - Sand } & 18 \mathrm{~m}^{3} \\ \text { - } & \text { Accelerator } & 530 \mathrm{~kg} \\ \text { - } & \text { Resin } & 351 \mathrm{patrons} \\ \text { - } & \text { Mesh } & 120 \mathrm{~kg} \\ \text { - } & \text { Rock bolts } & 117 \text { pieces }\end{array}$

During the construction of these $20 \mathrm{~m}$ ramp it was found that data on projected longitudinal profile is not fully realized, and that the whole route of ramp passes through the III category of rock material. This category of rock material has higher requirements in terms of supporting because of bigger rock pressure (Донева et al. 2012). Because of this, the amount of operating supplies for supporting are very different than the projected ones, which are given below:

$\begin{array}{lll}\text { - } & \text { Cement } & 12160 \mathrm{~kg} \\ \text { - } & \text { Sand } & 35.6 \mathrm{~m}^{3} \\ \text { - } & \text { Accelerator } & 1095 \mathrm{~kg} \\ \text { - } & \text { Resin } & 549 \mathrm{patrons} \\ \text { - } & \text { Mesh } & 240 \mathrm{~kg} \\ \text { - } & \text { Rock bolts } & 183 \text { pieces }\end{array}$

Based on previously presented data, it can be concluded that not devoting enough attention to exactly determine the structural and physical-mechanical characteristics of rock material along the route of facility can lead to numerous 
problems in the mining operation. Problems relate to several aspects of operations. Nowadays almost all mines are under concession of private companies, with the goals of increasing profits. Each year, they want from the management team, a cost plan which will anticipate these investments, including means for construction of an underground facility. If the backgrounds which the mine is obliged to give on designers are not good, this can lead to a difference between the estimated costs in project with the incurred ones. Therefore it is necessary within the mine, more attention to be devoted to research, not only of ore body, but also on the associated rocks. This is especially important in terms of mining facilities construction, because they are usually performed in barren rocks.

\section{CONCLUSION}

Of all that has been stated in this paper the following can be concluded:

- Before the construction of any mining facility, it is necessary for a research to be performed on the rock material along the route of the facility to make possible precise engineering - mining profiles;

- Good bases for design enable the conduction of a good project, which will determine more precisely the total cost of its implementation;

- $\quad$ This will improve the planning in the mine and the possibility for more frugal and efficient mining operation.

\section{REFERENCES}

[1] BRADY, B.H.G. and BROWN, E.T. (2004) Rock mechanics for underground mining. Queensland, Australia: University of Western Australia.

[2] ДОНЕВА, Н. (2011) Методологија за утврдувағе на функиионалната зависност на трошоците од видот на работната средина и големината на профилот при изработка на хоризонтална рударска просторија. Докторска дисертација (PhD), Универзитет „Гоце Делчев“ Штип.

[3] ДОНЕВА, Н., ДЕСПОДОВ, 3. и ХАЏИ-НИКОЛОВА, М. (2012) Влијание на видот на работна средина врз времето на изработка на хоризонтални рударски простории. Македонско рударство и геологија, 22, pp. 26-29.

[4] JOVANOVIĆ, P. (1994) Proektovanje i proračun podgrade horizontalnih rudarskih prostorija - knjiga 1. Beograd: Rudarsko-geološki fakultet.

[5] TORBICA, S. i PETROVIĆ, N. (1997). Metode i tehnologija podzemne eksploatacije neslojevitih ležišta. Beograd: Rudarsko-geološki fakultet. 